American Journal of Biochemistry and Biotechnology 5 (4): 153-161, 2009

ISSN 1553-3468

(C) 2009 Science Publications

\title{
Concomitant Down Regulation of Glycolytic Enzymes, Upregulation of Gluconeogenic Enzymes and Potential Hepato-Nephro-Protective Effects Following the Chronic Administration of the Hypoglycemic, Insulinotropic Citrullus colocynthis Pulp Extract
}

\author{
${ }^{1}$ Mohammad Dallak, ${ }^{2}$ Nabil Bashir, ${ }^{3}$ Mohammad Abbas, ${ }^{3}$ Riyadh Elessa \\ ${ }^{1}$ Mohamed Haidara, ${ }^{4}$ Mohammad Khalil and ${ }^{1}$ Mahmoud A. AL-Khateeb \\ ${ }^{1}$ Department of Physiology, College of Medicine, King Khalid University, \\ P.O. Box 641, Abha 61421, Saudi Arabia \\ ${ }^{2}$ Department of Biochemistry, Faculty of Medicine, \\ Jordan University of Science and Technology, Irbid 21110, Jordan \\ ${ }^{3}$ Department of Biochemistry, College of Medicine, King Khalid University, \\ P.O. Box 641, Abha 61421, Saudi Arabia \\ ${ }^{4}$ Division of Physiology, Department of Basic Medical Sciences, \\ Faculty of Medicine, King Fahad Medical City, Riyadh 11393, Saudi Arabia
}

\begin{abstract}
Background Citrullus colocynthis pulp seedless extract has been demonstrated to have antihyperglycemic and insulinotropic effects. Problem statement: The mechanism(s) underlying the antihyperglycemic and insulinotropic effects have not been investigated to date. Approach: The influence of Citrullus colocynthis pulp extract administered orally was studied in alloxan diabetic white albino rats. Rats were divided into four groups, the first group was normal non diabetic rats given normal saline orally and was named control group, the second group was diabetic rats given normal saline orally and were named normal saline treated-diabetic rats, the third and fourth group were diabetic rats treated with the pulp extract or glybenclamide (a positive control) orally. Plasma glucose, glycosylated hemoglobin and insulin were determined in all groups. The effect of pulp extract of this plant on liver and kidney tissues was also studied. The amount of insulin in $\beta$-cells of the Islets of Langerhans in all groups was assessed using immunohistochemistry procedure. Results: Treatment of diabetic rats with Citrullus colocynthis pulp extract $\left(300 \mathrm{mg} \mathrm{kg}^{-1}\right.$ body weight) resulted in a significant decrease in plasma glucose, glygosylated $\mathrm{Hb}$ and increased insulin levels. This significant increase in insulin may explain the increase in the activity of liver hexokinase, with concomitant decrease of glucose 6-phosphatase and fructose-1,6-bisphosphatase. Immunohistochemistry procedure showed that the amount of insulin in $\beta$-cells of the islets of Langerhans is greater in Citrullus colocynthis treated-diabetic rats in comparison to non-treated diabetic rats. Conclusion: The present study clearly demonstrated that the folk medicinal plant Citrullus colocynthis pulp extract possesses a hypoglycemic effect, through an increase in insulin production and the subsequent increase in activity of glycolytic enzyme and decrease in activity of enzymes of gluconeogenesis. The present study also showed that the pulp extract of this plant to may have protective effects on the liver and kidney.
\end{abstract}

Key words: Citrullus colocynthis, alloxan, diabetes and hypoglycemic

\section{INTRODUCTION}

Diabetes Mellitus (DM) is a metabolic disorder of multiple etiologies, characterized by chronic hyperglycemia with disturbances of carbohydrate, fat and protein metabolism resulting from defects in insulin secretion, insulin action or both ${ }^{[1]}$ Globally, the estimated incidence of DM and projection for year 2010, as given by International Diabetes Federation is 239 million $^{[2]}$.

Both acute and late diabetic complications are commonly encountered. The long-term complications represented by cardiovascular and cerebro-vascular diseases, nephropathy, retinopathy and neuropathies are

Corresponding Author: Mohammad Dallak, Department of Physiology, College of Medicine, King Khalid University, P.O. Box 641, Abha 61421, Saudi Arabia 
already major causes of morbidity, disability and premature death in countries of the Eastern Mediterranean region ${ }^{[3]}$. The underlying causes of diabetic complications have been attributed to hyperglycemia which results in oxidative stress, alterations in enzyme activities, protein glycosylation and several structural changes ${ }^{[4]}$.

Traditional herbal remedies have been used for the treatment of diabetes mellitus in many communities, especially in Asia and Saudi Arabia ${ }^{[5]}$. There is an increasing demand by patients to use natural products with antidiabetic activity, because insulin and oral hypoglycemic drugs have undesirable side effects ${ }^{[6]}$ Extracts of various plant materials capable of decreasing blood sugar have been tested in experimental animal models and their effects confirmed $^{[7]}$. It has been documented that several medicinal plants show their hypoglycemic effects associated with a significant alteration in the activity of liver hexokinase ${ }^{[8]}$ and glucokinase ${ }^{[9]}$. In addition, Bopanna et al. ${ }^{[8]}$ and Eskander et al. ${ }^{[10]}$ demonstrated that the administration of several herb extracts could restore the changes in the activities of serum enzymes, like Alkaline Phosphatase (ALP), Acid Phosphatase (ACP) and transaminases: Aspartate Aminotransferase (AST) and Alanine Aminotransferase (ALT).

Citrullus colocynthis (Cucurbitaceae), commonly known as "bitter apple", "colosynth", "vine-of-Sodom" and "tumba" is a tropical plant that grows abundantly in the Arabian countries and widely in other parts of the world. In the traditional medicine, this plant has been used to treat constipation ${ }^{[11]}$, Diabetes ${ }^{[12]}$, edema, fever, jaundice leukemia, bacterial infections, cancer and used as an abortifacient ${ }^{[13]}$.

Thus, we considered it weighs heavily to check whether there is any scientific basis for the wide use of this plant in the Arabian countries as a hypoglycemic agent to treat diabetes. The aim of the present study is to investigate the mechanisms underlying the hypoglycemic effect of the pulp extract of Citrullus colocynthis in alloxan-induced diabetic rats.

\section{MATERIALS AND METHODS}

Preparation of Citrullus colocynthis pulp extract: Fresh one kilogram of Citrullus colocynthis fruits was collected from Aseer area, southwestern region of Saudi Arabia. Mature black seeds were separated manually from the pulp of the fruits and then the pulp was dried and grinded with a grinder (Molinex) into a powder prepared for extraction. The pulp powder was extracted by one liter of water-ethanol mixture $(80 / 20, v / v)$ for 6 $\mathrm{h}$, this step was repeated three times ${ }^{[14]}$. The filtrate was pooled and concentrated under vacuum at temperature (not exceeding $50^{\circ} \mathrm{C}$ ) and dissolved in freshly prepared normal saline to a final concentration of $300 \mathrm{mg} \mathrm{mL}^{-1}$ for further use.

Experimental animals: Male albino Wistar rats (150$200 \mathrm{~g}$ ) bred in the Central Animal House, Science College, King Khalid University, were used in this study. The animals were fed on rat chow and water ad libitum. The animals were maintained in their respective groups for 60 days. All studies were conducted in accordance with the National Institute of Health's Guide for the Care and Use of Laboratory Animals ${ }^{[15]}$.

Experimental induction of diabetes: Diabetes was induced in male Wistar albino rats by intraperitoneal administration of alloxan monohydrate $\left(150 \mathrm{mg} \mathrm{kg}^{-1}\right.$ body weight ${ }^{[16]}$, dissolved in normal saline. Since alloxan is capable of producing fatal hypoglycemia as a result of massive pancreatic insulin release, rats were treated with $30 \%$ glucose solution orally at different time intervals after $6 \mathrm{~h}$ of alloxan induction and 5\% glucose solution was kept in bottles in their cages for the next $24 \mathrm{~h}$ to prevent hypoglycemia. After 10 days, rats with diabetes mellitus having glycosuria (indicated by Benedict's test) and hyperglycemia, with blood glucose range of $250-375 \mathrm{mg} \mathrm{dL}^{-1}$, were used for this study.

Experimental design: The rats were divided into four groups comprising six animals in each group $(n=6)$. All treatments were given orally to experimental rats using cavage needle at a single dose day $^{-1}$. The rats were treated for 30 days as follows:

Group 1: Control rats, given only normal Saline $\left(1 \mathrm{~mL} \mathrm{~kg}^{-1}\right)$

Group 2: Non-treated diabetic group, given only normal Saline $\left(1 \mathrm{~mL} \mathrm{~kg}^{-1}\right)$.

Group 3: Diabetic group treated with glibenclamide $\left(600 \mathrm{mg} \mathrm{kg}^{-1} \text { body wt day }{ }^{-1}\right)^{[17]}$.

Group 4: Diabetic group treated orally with $1 \mathrm{~mL} \mathrm{~kg}^{-1}$ of Citrullus colocynthis pulp extract $\mathrm{kg}^{-1}$ (300 $\mathrm{mg} \mathrm{kg}^{-1}$ body weight day ${ }^{-1}$ ).

Collection of blood plasma and preparation of homogenate: At the end of day 30, the rats were subjected to over night fasting and then were scarified 
by cervical dislocation and blood samples were collected directly into heparinized tubes and then were centrifuged at $3000 \mathrm{rpm}$ for $10 \mathrm{~min}$ to obtain plasma. The liver and kidney were then quickly removed, washed in ice-cold, isotonic saline and blotted individually on ash-free filter paper. The tissues were then homogenized in $0.1 \mathrm{M}$ Tris- $\mathrm{HCl}$ buffer, $\mathrm{pH} 7.4$ using a Potter-Elvejham homogenizer at $4^{\circ} \mathrm{C}$ with a diluting factor of 4 , the crude tissue homogenate was then centrifuged at a speed of $9000 \mathrm{rpm}$ for $15 \mathrm{~min}$ at room temperature and the supernatant was kept at $-20^{\circ} \mathrm{C}$ for biochemical analysis. The homogenate was used for the estimations of tissue enzymes activities.

Biochemical assays: Blood glucose, uric acid and creatinine were estimated using a commercial diagnostic kit (Sigma chemical Co., Louis, MO, USA). Plasma insulin was determined using a radioimmunoassay kit (Boerhringer Mannheim kit, Germany). C-peptide was determined using diagnostic kit (Rat C-Peptide I and II EIA Kit, Alpco diagnostics).

Glycosylated hemoglobin was determined by BioRad automatic instrument (D10). Urea was determined by the method of Natelson ${ }^{[18]}$. The albumin content was estimated by the method described by Reinhold ${ }^{[19]}$. The protein content in the plasma was estimated by the method of Lowry ${ }^{[20]}$. The enzymes: Aspartate aminotransferase (AST), Alanine aminotransferase (ALT) and Alkaline phosphatase (ALP), were assayed by the method of King and Armstrong ${ }^{[21]}$ and the enzyme $\gamma$-glutamyl transpeptidase $(\gamma$-GT) was assayed by the method of Rosalki and $\mathrm{Rau}^{[22]}$, Liver homogenate was used for the estimations of hexokinase ${ }^{[23]}$, glucose 6-phosphatase ${ }^{[24]}$ and fructose1,6-bisphosphatase ${ }^{[25]}$. Measurement of liberated inorganic phosphorus was assayed according to Fiske and Subbarow ${ }^{[26]}$. All spectrophotometric measurements were carried out using a Janway UVvisible spectrophotometer (Janway 6405 UV/Vis, Janway Ltd., UK).

Tissue characterization procedure: Pancreatic tissues were taken from the anaesthetized control rats. They were stained with heamatoxylin and eosin for tissue characterization and organ identification. Histological specimens were examined under the light microscope.

Immunohistochemistry procedure: Histological sectiona $\mathrm{f}$ pancreases $(5 \mu \mathrm{m})$ were cut from paraffin blocks with rotary microtome. Immunohistochemistry was performed to localize insulin in the pancreatic tissue by Avidin-Biotin Complex (ABC) technique ${ }^{[27]}$. Specific monoclonal mouse antibodies against human insulin protein (Zymed 18-0066, Zymed laboratories, Inc., South San Francisco, CA, USA) were used at a dilution of 1:50. The immunohistochemical procedure was performed to all sections by the following procedure: First, sections were deparaffinized in Xylen, dehydrated in a descending ethanol series (100, 90 and $70 \%$ ) and then immersed in a retrieval solution (DAKO 51700, DAKO Diagnostics S.A., Barcelona. Spain) and washed by Phosphate Buffer Saline (PBS) for $5 \mathrm{~min}$. Activity of endogenous peroxides was inhibited with $3 \% \mathrm{H}_{2} \mathrm{O}_{2}$ in absolute methanol for $30 \mathrm{~min}$ and then washed with PBS. Blocking of non-specific binding of antibodies was done by incubation the pancreatic slides with normal goat serum (DAKO X 909, DAKO Diagnostics SA, Barcelona, Spain) diluted with PBS 1:4. Pancreatic slides were incubated with monoclonal mouse antibody against human insulin protein, diluted 1:400 for $2 \mathrm{~h}$ at room temperature then they were Washed in PBS three times for $3 \mathrm{~min}$. the slides were then incubated with biotinylated anti-mouse IgG (DAKO LAB 2 Kit, DAKO Diagnostics SA) followed by Washing in PBS three times for $3 \mathrm{~min}$. all slides were then Incubated with ABC complex (DAKO LAB 2 Kit, DAKO Diagnostics SA) and Washed in PBS three times for $3 \mathrm{~min}$, Peroxidase detection was done using 3, 3 Diaminobenzidine tetrahydrochloride as a chromogen (DAB). After that the sections were washed in tap water for $5 \mathrm{~min}$ then mounted in DAKO faramouunt. Hematoxylin was used as a counterstain. PBS was used instead of monoclonal antibodies as negative control.

Statistical analysis: Results were expressed as the mean value \pm SEM. Statistical differences between groups were assessed by Student's t test. Values of $\mathrm{p}<0.05$ were considered significantly different.

\section{RESULTS}

Table 1 showed a significant increase in the level of blood glucose, a decrease in plasma insulin and Cpeptide in non-treated diabetic rats when compared to control group. Administration of Citrullus colocynthis or glibenclamide to diabetic rats significantly decreased the level of blood glucose and increased plasma insulin and C-peptide in comparison to non-treated diabetic group.

Table 1 also showed that the level of protein in plasma was found to be reduced in non-treated diabetic rats when compared to control group. This lowered level of protein in non-treated diabetic rats, has also increased after Citrullus colocynthis or glibenclamide treatment. 
Am. J. Biochem. \& Biotech., 5 (4): 153-161, 2009

Table 1: Plasma parameters of control and experimental groups of rats

\begin{tabular}{|c|c|c|c|c|}
\hline Parameter & Control & Non-treated diabetic & Diabetic + glibenclamide & Diabetic + C.c $\left(300 \mathrm{mg} \mathrm{kg}^{-1}\right)$ \\
\hline Blood glucose $\left(\mathrm{mg} \mathrm{dL}^{-1}\right)$ & $101.00 \pm 5.20$ & $298.00 \pm 6.3^{*}$ & $96.40 \pm 5.2 *$ & $122.50 \pm 5.5^{*}$ \\
\hline Plasma insulin $\left(\mu \mathrm{U} \mathrm{mL}{ }^{-1}\right)$ & $18.00 \pm 0.60$ & $6.30 \pm 0.44 *$ & $11.40 \pm 0.55^{*}$ & $10.90 \pm 0.50 *$ \\
\hline C-peptide $\left(\mathrm{pmol} \mathrm{L}^{-1}\right)$ & $254.20 \pm 11.2$ & $132.40 \pm 11.1^{*}$ & $222.40 \pm 8.8^{*}$ & $210.10 \pm 12.1^{*}$ \\
\hline Protein $\left(\mathrm{g} \mathrm{dL}^{-1}\right)$ & $7.00 \pm 0.90$ & $4.20 \pm 0.60 *$ & $7.30 \pm 0.78 *$ & $6.32 \pm 0.50 *$ \\
\hline Albumin $\left(\mathrm{g} \mathrm{dL}^{-1}\right)$ & $3.62 \pm 0.45$ & $1.63 \pm 0.18^{*}$ & $3.43 \pm 0.17 *$ & $3.10 \pm 0.34 *$ \\
\hline Urea $\left(\mathrm{mg} \mathrm{dL}^{-1}\right)$ & $22.60 \pm 1.60$ & $39.60 \pm 2.0^{*}$ & $22.20 \pm 1.70^{*}$ & $26.80 \pm 1.62 *$ \\
\hline Uric acid $\left(\mathrm{mg} \mathrm{dL}^{-1}\right)$ & $1.00 \pm 0.24$ & $2.20 \pm 0.20^{*}$ & $1.08 \pm 0.06^{*}$ & $1.56 \pm 0.03 *$ \\
\hline Creatinine $\left(\mathrm{mg} \mathrm{dL}^{-1}\right)$ & $0.89 \pm 0.06$ & $2.45 \pm 0.35^{*}$ & $1.34 \pm 0.07 *$ & $1.43 \pm 0.02 *$ \\
\hline Glycosylated $\mathrm{Hb}\left(\mathrm{mg} \mathrm{g}^{-1}\right.$ of $\left.\mathrm{Hb}\right)$ & $0.23 \pm 0.02$ & $0.61 \pm 0.06^{*}$ & $0.24 \pm 0.02 *$ & $0.31+0.03^{*}$ \\
\hline
\end{tabular}

Values are given as mean \pm SD for groups of six rats each. Values are statistically significant* at $\mathrm{p}<0.05$. Diabetic rats were compared with control rats; Citrullus colocynthis treated-diabetic rats were compared with diabetic rats; glibenclamide treated-diabetic rats were compared with diabetic rats

Table 2: Activities of Aspartate aminotransferase (AST), Alanine aminotransferase (ALT), alkaline phospahtase (ALP) and glutamyl transferase $(\gamma \mathrm{GT})$ in plasma, liver and kidney of control and experimental groups of rats

\begin{tabular}{|c|c|c|c|c|}
\hline Parameter & Control & Non-treated diabetic & Diabetic + glibenclamide & Diabetic + C.c $\left(300 \mathrm{mg} \mathrm{kg}^{-1}\right)$ \\
\hline \multicolumn{5}{|l|}{ Plasma } \\
\hline AST & $79.400 \pm 6.22$ & $122.00 \pm 5.22 *$ & $85.20 \pm 2.30^{*}$ & $87.50 \pm 2.35^{*}$ \\
\hline ALT & $34.200 \pm 2.50$ & $67.20 \pm 3.50 *$ & $37.20 \pm 2.45^{*}$ & $42.00 \pm 2.60 *$ \\
\hline ALP & $76.000 \pm 3.92$ & $143.10 \pm 5.31 *$ & $81.70 \pm 5.52 *$ & $91.50 \pm 3.65^{*}$ \\
\hline g-GT & $12.900 \pm 1.30$ & $27.30 \pm 2.44 *$ & $16.30 \pm 2.57 *$ & $16.20 \pm 1.70^{*}$ \\
\hline \multicolumn{5}{|l|}{ Liver } \\
\hline AST & $721.000 \pm 11.2$ & $980.40 \pm 15.3^{*}$ & $734.70 \pm 12.1 *$ & $765.00 \pm 12.4^{*}$ \\
\hline ALT & $922.300 \pm 14.2$ & $1311.00 \pm 10.4^{*}$ & $933.50 \pm 15.0^{*}$ & $978.20 \pm 14.7 *$ \\
\hline ALP & $0.110 \pm 0.04$ & $0.32 \pm 0.03^{*}$ & $0.18 \pm 0.01 *$ & $0.21 \pm 0.012^{*}$ \\
\hline $\begin{array}{l}\gamma \mathrm{T} \Gamma- \\
\text { Kidney }\end{array}$ & $4.000 \pm 0.40$ & $6.22 \pm 0.60^{*}$ & $4.21 \pm 0.40^{*}$ & $4.20 \pm 0.30^{*}$ \\
\hline $\begin{array}{l}\text { Kidney } \\
\text { AST }\end{array}$ & $790.000 \pm 13.0$ & $780.50 \pm 14.2$ & $790.20 \pm 13.1$ & $775.00 \pm 10.0$ \\
\hline ALT & $860.400 \pm 1580$ & $854.20 \pm 21.1$ & $844.70 \pm 12.1$ & $832.60 \pm 13.1$ \\
\hline ALP & $0.180 \pm 0.01$ & $0.52 \pm 0.04 *$ & $0.27 \pm 0.02 *$ & $0.30 \pm 0.02 *$ \\
\hline$\gamma \mathrm{G} \Gamma-$ & $2.651 \pm 0.20$ & $5.780 \pm 0.46^{*}$ & $3.34 \pm 0.14^{*}$ & $3.35 \pm 0.14 *$ \\
\hline
\end{tabular}

Values are given as mean \pm SD for groups of six rats each. Values are statistically significant* at $\mathrm{p}<0.05$. Diabetic rats were compared with control rats; Citrullus colocynthis treated-diabetic rats were compared with diabetic rats; glibenclamide treated diabetic rats were compared with diabetic rats. Units of measurement $\left(\mathrm{L}^{-1}\right)$ for AST and ALT: $\mu \mathrm{mol}$ of pyruvate liberated/hr; for ALP: $\mu \mathrm{mol}$ of phenol liberated/min and for $\gamma$-GT: mol of p-nitro aniline liberated/min

Table 1 also showed that urea, uric acid and creatinine levels were significantly elevated in nontreated diabetic rats when compared to control group. Oral administration of Citrullus colocynthis pulp extract or glibenclamide for 30 days significantly lowered their levels in comparison to non-treated diabetic rats.

Table 1 also showed that there is a significant increase in glycosylated hemoglobin in non-treated diabetic rats when compared to control rats. Oral administration of Citrullus colocynthis or glibenclamide significantly decreased glycosylated hemoglobin in comparison to non-treated diabetic rats.

Table 2 showed the activities of Aspartate aminotransferase (AST), Alanine aminotransferase (ALT), Alkaline Phosphatase (ALP) and Gamma Glutamyl Transferase $(\gamma$-GT) in plasma, liver and kidney. In comparison to control rats, the activities of these enzymes were found to be significantly increased in the plasma and liver of non-treated diabetic rats. In the kidney of non-treated diabetic rats, the activities of ALP and $\gamma$-GT were increased, while the activities of
AST and ALT were not altered. Oral administration of Citrullus colocynthis for 30 days resulted in the decrease of the activities of AST, ALT, ALP and $\gamma$-GT in the plasma, liver and kidney of diabetic rats, such effect was also noted in glibnclamide treated-diabetic rats.

Table 3 showed that the activity of hepatic hexokinase is significantly decreased while those of glucose-6-phosphatase and fructose-1,6-bisphosphatase were significantly elevated in non-treated diabetic rats as compared to control group. Administration of Citrullus colocynthis or glibenclamide increased the activity of hexokinase and decreased the activities of glucose 6-phosphatase and fructose-1,6- bisphosphatase as compared to non treated-diabetic rats.

Figure 1 shows photomicrographs of pancreatic tissues taken from control group rats and stained with Eosin-Hamatoxylin for characterization. The arrow indicates the exocrine component of the pancreas which consists of highly packed secretory acini, while the arrowhead represents the endocrine tissue of the pancreas which is known as islets of Langerhans. 
Am. J. Biochem. \& Biotech., 5 (4): 153-161, 2009

Table 3: Activities of liver tissue enzymes in control and experimental groups of rats

\begin{tabular}{|c|c|c|c|c|}
\hline Parameter & Control & Non-treated diabetic & Diabetic + glibenclamide & Diabetic + C.c $\left(300 \mathrm{mg} \mathrm{kg}^{-1}\right)$ \\
\hline \multicolumn{5}{|l|}{ Hexokinase: } \\
\hline (Unit a mg ${ }^{-1}$ protein) & $0.233 \pm 0.02$ & $0.0742 \pm 0.01 *$ & $0.210 \pm 0.02 *$ & $0.200 \pm 0.02 *$ \\
\hline $\begin{array}{l}\text { Glucose-6-phosphatase } \\
\text { (Unit b mg }{ }^{-1} \text { protein) }\end{array}$ & $0.193 \pm 0.01$ & $0.5320 \pm 0.02 *$ & $0.165 \pm 0.02 *$ & $0.26 \pm 0.04 *$ \\
\hline $\begin{array}{l}\text { Fructose } 1,6 \text {-biphosphatese } \\
\text { (Unit } \mathrm{c} \mathrm{mg}^{-1} \text { protein) }\end{array}$ & $0.432 \pm 0.02 *$ & $0.7210 \pm 0.06^{*}$ & $0.397 \pm 0.03^{*}$ & $0.478 \pm 0.02 *$ \\
\hline
\end{tabular}

Values are given as mean \pm SD for groups of six rats each. Values are statistically significant* at $p<0.05$. Diabetic rats were compared with control rats; Citrullus colocynthis treated-diabetic rats were compared with diabetic rats; glibenclamide treated-diabetic rats were compared with diabetic rats. (a): $\mu$ moles of glucose phosphorylated/h; (b): $\mu$ moles of pi liberated $/ \mathrm{min}$ (c): $\mu$ moles of pi liberated $/ \mathrm{min}$

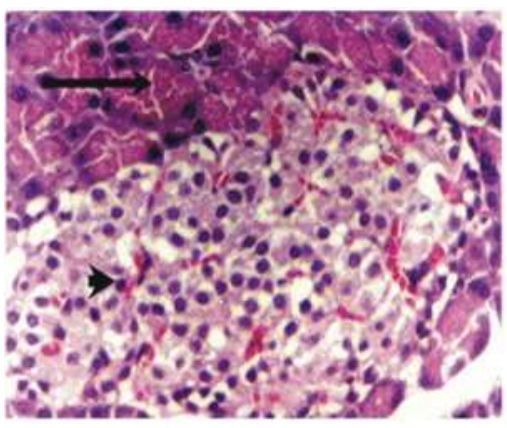

Fig. 1: A photomicrograph of pancreatic tissue of Control rats stained with Hematoxylin and Eosin for tissue characterization. Original magnification X100. The arrow indicates the exocrine component of the pancreas which consists of highly packed secretory acini, while the arrow head represents the endocrine tissue of the pancrease (islets of langerhans)

Figure 2b-e showed photomicrographs of pancreatic tissues processed by immunohistochemistry for detection of insulin in the islets of Langerhans of all rats groups. Brown coloration indicates positive insulin immunoreactivity. The intensity of brown coloration correlates with amount of insulin present in these cells. Figure $2 \mathrm{a}$ is a photomicrograph of pancreatic tissues taken from control rats (negative control) stained with Eosin and Hematoxyline. However, the primary antibody in the immunohistochemistry procedure was replaced with normal saline.

Figure $2 b$ shows a highly positive immunoreactivity of insulin (dark brown coloration) in the pancreatic tissues of control rats.

In comparison to Fig. 2b (Control group), Fig. 2c shows a highly reduced intensity of brown coloration in the islets of Langerhans of non-treated diabetic rats. Figure $2 \mathrm{~d}$ and $\mathrm{e}$ were taken from glibenglamide and Citrullus colocynthis treated rats respectively. They show a significant increased in the intensity of the brown coloration in the islets of Langerhans as compared to Fig. 2c (non-treated diabetic rats).

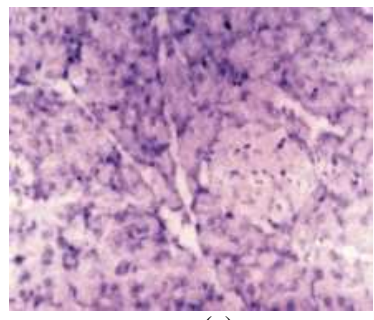

(a)

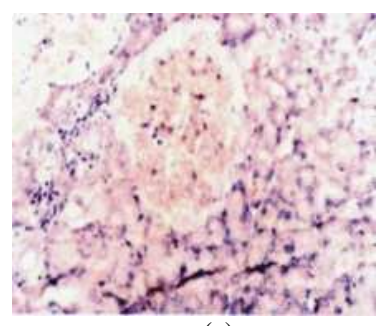

(c)

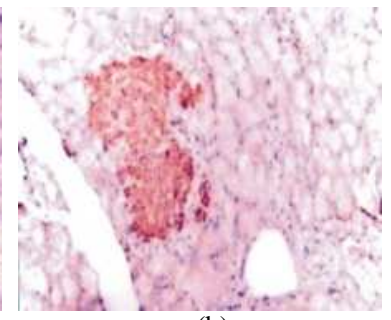

(b)

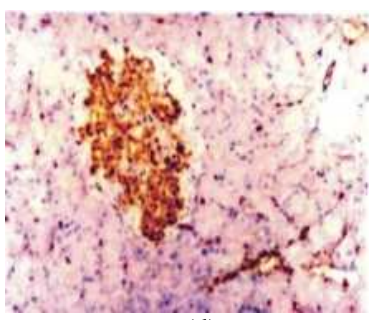

(d)

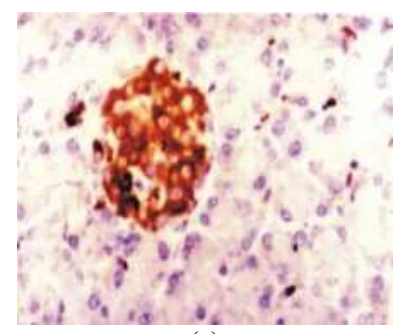

(e)

Fig. 2: Photomicrographs of insulin immunoreactivity in pancreatic tissues of all rats groups. Using $\mathrm{ABC}$ technique. Counterstained with Eosin and hematoxylin. Original magnification X100. (a) negative control; (b) control rats; (c) nontreated diabetic rats; (d) diabetic rats treated with glibenclamide; (e) diabetic rats treated with Citrullus colocynthis

\section{DISCUSSION}

Diabetes Mellitus (DM) is a chronic disease characterized by high blood glucose levels due to an absolute or relative deficiency of circulating insulin levels. Although various types of oral hypoglycemic 
agent are currently available along with insulin for treating DM, there is a growing interest in herbal remedies due to the side-effects associated with the existing therapeutic hypoglycemic agents ${ }^{[6]}$.

Animal models have extensively been used to study diabetes mellitus ${ }^{[14]}$. In the present study diabetes was introduced in rats using intraperitoneal administration of alloxan and the hypoglycemic and protective effect of Citrullus colocynthis was investigated.

Blood sugar level increased (hyperglycemia) in alloxan-treated rats, since alloxan causes a massive reduction in insulin release, by the destruction of the beta-cells of the islets of Langerhans ${ }^{[28]}$. We have observed a significant decrease in blood glucose in Glibinclamide or Citrullus colocynthis-treateddiabetic rats, when compared with non-treateddiabetic rats (Table 1). The possible mechanism of Citrullus colocynthis hypoglycaemic action may be through potentiation of pancreatic secretion of insulin from beta cells of islets, or due to enhanced transport of blood glucose to the peripheral tissue. In support of the former assumption our results showed an increase in the level of insulin in diabetic rats treated with Citrullus colocynthis and also we proved an increase in the immunoreactivity of insulin present in the beta cells of the pancreas. The measurement of both $\mathrm{C}$ peptide and insulin levels have been reported to be a valuable index of insulin secretion rather than insulin alone ${ }^{[29]}$. C peptide and insulin are the products of the enzymatic cleavage of proinsulin and secreted into the circulation in equimolar concentrations. In this study, the plasma C-peptide and insulin levels were significantly higher in the glibnclamide and Citrullus colocynthis treateddiabetic rats in comparison to non-treated diabetic rats (Table 1). In this context, a number of other plants have also been reported to have hypoglycemic and insulin release stimulatory effects ${ }^{[30]}$. The glycosylated hemoglobin levels in plasma gives an idea about patient's overall glucose levels in the preceding 6-8 weeks. Glycosylated hemoglobin comprises about 3.4-5.8\% total hemoglobin in normal human red cells, but it is increased in patients of overt diabetes ${ }^{[31]}$. It is found to increase in diabetic patients up to 16 percent and the amount of this increase is directly proportional to the long lasting fasting blood sugar level. In our study the high level of glycosylated hemoglobin had reduced after one month of treatment by Citrullus colocynthis, indicating the long lasting effect of this plant pulp extract as a hypoglycemic agent. Associated with the changes in plasma concentration of insulin are changes in hepatic enzymes activity. Hexokinase is a glycolytic enzyme, whose activity is induced by insulin ${ }^{[32]}$. As expected the activity of this enzyme is reduced in non- treated diabetic rats compared to control group (Table 3). The activity of this enzyme had increased after one month of treatment by Citrullus colocynthis, a result that would be consequent to the increase in insulin concentration.

Glucose-6-phosphatase and fructose-1,6diphosphatase are enzymes of gluconeogenesis, whose activity are repressed by insulin ${ }^{[32]}$. As expected the activity of these enzymes is increased in non-treated diabetic rats compared to control rats (Table 3). The activity of these two enzymes had decreased after one month of treatment by Citrullus colocynthis, which would be consequent to the increase in insulin concentration.

Reduction in plasma total protein and albumin level was observed in non-treated diabetic rats and this is consistent with the results obtained by Tuvemo et al. ${ }^{[33]}$. The decrease in protein and albumin may be due to microproteinuria and albuminuria, which are important clinical markers of diabetic nephropathy ${ }^{[34]}$ and/or may be due to increased protein catabolism in diabetes $^{[35]}$. In our study plasma total protein and albumin levels have increased after one month of treatment by Citrullus colocynthis. This increase could be due to the increase in concentration of insulin, which is known as anabolic hormone and/or could be due to improvement in renal function. Such improvement of serum protein and albumin was previously observed after the oral administration of Balanites aegyptiaca to experimentally diabetic rats ${ }^{[36]}$.

Diabetes mellitus also causes renal damage due to abnormal glucose regulation, including elevated glucose and glycosylated protein tissue levels, haemodynamic changes within the kidney tissue and increased oxidative stress ${ }^{[37]}$. Plasma urea, uric acid and creatinine levels were higher in non-treated diabetic rats than in control group (Table 1). Damage or loss of glomeruli in diabetes could lead to such an increase. The level of these substances had reduced after one month of treatment by Citrullus colocynthis, which may indicate the ability of this plant pulp extract to enhance renal function. These results are in agreement with other previous studies on the mesocarp extract of Balanites aegyptiaca ${ }^{[38]}$.

In transaminase reaction, one amino acid is converted to the corresponding keto acids with simultaneous conversion of another keto acid to an amino acid. The aminotransferases (enzymes) involved in this reaction are: Aspartate aminotransferase (AST) and Alanine aminotransferase (ALT) ${ }^{[39]}$. These enzymes are present in hepatocytes and leak into blood with liver cell damage. In our study, the activity of theses enzymes in plasma and liver were higher in nontreated diabetic rats than in control group (Table 3). 
This increase may reflect hepatocelluar damage associated with diabetes ${ }^{[40]}$. The activity of these enzymes have reduced after one month of treatment by Citrullus colocynthis, indicating that this plant pulp extract could, as well, have the ability to repair liver tissue damage. The enzyme Alkaline Phosphatase (ALP) is present in the canalicular and sinusoidal membrane of the liver and is also present in many other tissues. In the present study activity of this enzyme is raised in plasma, liver and kidney of non-treated diabetic rats compared to control group (Table 3), this increase is often noticed in cholestasis ${ }^{[41]}$. One month of treatment with Citrullus colocynthis has led to a reduction in the activity of this enzyme, a result that could support our earlier deduction that this plant pulp extract may have the ability to repair live and kidney damage. $\gamma$-glutamyl transpeptidase is a microsomal enzyme that is present in many tissues, as well as the liver ${ }^{[42]}$. In cholestasis the $\gamma$-GT rises in parallel with ALP as it has a similar pathway of excretion. The increase in $\gamma$-GT seen in non-treated diabetic rats has also reduced after 1 month of treatment by Citrullus colocynthis, indicating, again, the healing ability of this plant pulp extract on tissues of liver and kidney.

\section{CONCLUSION}

In conclusion, we have demonstrated that the folk medicinal plant Citrullus colocynthis pulp extract possesses a hypoglycemic effect, through an increase in insulin production and the subsequent increase in activity of glycolytic enzyme (hexokinase) and the decrease in activity of enzymes of gluconeogenesis (Glucose-6-phosphatase and Fructose-1,6biphosphatase). The present study also showed that the pulp extract of this plant may have the ability to enhance liver and kidney functions.

\section{REFERENCES}

1. Baquer, N.Z., D. Gupta and J. Raju, 1998. Regulation of metabolic pathways in liver and kidney during experimental diabetes: Effects of antidiabetic compounds. Ind. J. Clin. Biochem., 13: 63-80. DOI: 10.1007/BF02867866

2. Karastergiou, K. and J.C. Kaski, 2008. Medical management of the diabetic patient with coronary artery disease. Curr. Pharm. Des., 14: 2527-2536. PMID: 18991670

3. Akbar, D., S. Mira, T. Zawawi and H. Malibary, 2000. Sub clinical diabetic neuropathy. A common complication in Saudi diabetics. Saudi Med. J., 21: 433-437.

http://www.ncbi.nlm.nih.gov/pubmed/11500676
4. Akpan, H.B., AK. Adefule, F.A. Fakoya and E.A. Caxton-Martins, 2007. Evaluation of LDH and G6-PDH activities in auditory relay centers of streptozocin-induced diabetic wistar rats. J. Anal. Sci., 1: 21-25.

5. Alrowaise, N.A., 2002. Herbal medicine in the treatment of diabetes mellitus. Saudi Med. J., 23: 1327-1331.

http://www.ncbi.nlm.nih.gov/pubmed/12506289

6. Kameswara, R.B. and C.H. Appa, 2001. Hypoglycemic and antihyperglycemic activity of alternifolium Walp. seed extracts in normal and diabetic rats. Phytomedicine, 8: 88-93. http://linkinghub.elsevier.com/retrieve/pii/S094471 1304700136

7. Bopanna, K.N. and S.P. Rathod, 1997. Antidiabetic and antihyperlipaemic effects of neem seed kernel powder on alloxon diabetic rabbits. Ind. J. Pharmacol., 29: 162-167. http://indianmedicine.eldoc.ub.rug.nl/root/B/7454/

8. Bopanna, K.N., J. Kannan, S. Godgil, R. Balaraman and S.P. Rathod, 1997. Antidiabetic and antihyperlipidemic effects of neem seed kernel powder on alloxan-diabetic rabbits. Ind. J. Pharmacol., 29: 162-172.

9. Kumari, K., B.C. Mathew and K.T. Augusti, 1995. Antidiabetic and hypolipidemic effect of S-methyl cysteine msulfoxide isolated from Allium cepa Linn. Ind. J. Biochem. Biophys., 32: 49-54. http://www.ncbi.nlm.nih.gov/pubmed/7665195

10. Eskander, E.F., H.W. Jun, K.A. Ibrahim and W.E. Abdelal, 1995. Hypoglycaemic effect of a herbal formulation in alloxan-induced diabetic rats. Egypt J. Pharm. Sci., 36: 253-270. http://cat.inist.fr/?aModele $=$ afficheN\&cpsidt $=1045$ 2780

11. Alkofahi, A., R. Batshoun, W. Owis and N. Najib, 1996. Biological activity of some Jordanian plants extracts. Fitoterapia, 5: 435-442. http://cat.inist.fr/?aModele $=$ afficheN\&cpsidt $=2522044$

12. Ziyyat, A. and A. Legssyer, 1997. Phytotherapy of hypertension and diabetes in oriental Morocco. J. Ethanopharmacol., 58: 45-54. DOI: 10.1016/S0378-8741(97)00077-9

13. Madari, H. and R.S. Jacobs, 2004. An analysis of cytotoxic botanical formulations used in the traditional medicine of ancient Persia as abortifacient. J. Nat. Prods., 67: 1204-1210. http://www.ncbi.nlm.nih.gov/pubmed/15332833

14. Namila, R., M. Roye and G. Ribes, 2000. Insulinotropic effect of Citrullus colocynthis fruit extracts. Planta Med., 66: 418-423. http://www.ncbi.nlm.nih.gov/pubmed/10909260 
15. National Institute of Health, 1996. Guide for the care and use of laboratory animals. revised. DHEW Publication (NIH), Office of Science and Health Reports, DRR/NIH, Bethesda, MD. http://www.nap.edu/openbook.php?record_id=5140

16. Alarcon-Aguilar, F.J., M. Jimenez-Estrad and R. Reyes-Chilpa et al., 2000. Hypoglycemic effect of extracts and fractions from Psacalium decompositum in healthy and alloxan-diabetic mice. J. Ethnopharmacol., 72: 21-27. http://grande.nal.usda.gov/ibids/index.php?mode2= detail\&origin=ibids_references\&therow $=134457$

17. Ananthi, J., A. Prakasam and K.V. Pugalendi, 2003. Antihyperglycemic activity of eclipta alba leaf on alloxan-induced diabetic rats. Yale J. Biol. Med., 76: 97-102. http://cat.inist.fr/?aModele $=$ afficheN\&cpsidt $=1703$ 7937

18. Natelson, S., 1957. Microtechniques of Clinical Chemistry for the Routine Laboratory. Springfield, Illinois, pp: 381.

19. Reinhold, J., 1980. Determination of Serum Total Protein, Albumin and Globulin Fractions by the Biuret Method. In: Practical Clinical Biochemistry, Varley, H., A.H. Gowen Lock and M. Bell (Eds.), 5th Edn., William Heinemann, London, pp: 45-47.

20. Lowry, O.H., N.J. Rosenbrough, A.L. Farr and R.L. Randall, 1951. Protein measurement with the Folin phenol reagent. J. Biol. Chem., 193: 264-275. http://www.ncbi.nlm.nih.gov/pubmed/14907713

21. King, K.J. and A.L. Armstrong, 1988. Calcium, Phosphorus and Phosphatase. In: Practical Clinical Biochemistry, Varley, H. (Ed.), 4th Edn., CBS Publishers, New Delhi, pp: 457-461.

22. Rosalki, S.B. and D. Rau, 1972. Serum Glutamyl transpeptidase activity in alcoholism. Clin. Chim. Acta, 39: 41-47. http://www.ncbi.nlm.nih.gov/pubmed/5038763

23. Branstrup, N. and M. Bruni, 1957. Determination of hexokinase in tissues. J. Gerontol., 12: 166-171.

24. Koide, H. and T. Odo, 1959. Pathological occurrence of glucose-6-phosphatase in serum liver diseases. Clin. Chem. Acta, 4: 554-61. http://www.ncbi.nlm.nih.gov/pubmed/14410580

25. Gancedo, J.M. and C. Gancedo, 1971. Fructose 1, 6 bisphosphatase, phosphofructokinase and glucose6-phosphate dehydrogenase from fermenting yeast. Arch. Microb., 76: 132-138. http://www.ncbi.nlm.nih.gov/pubmed/4324161

26. Fiske, G.H. and Y. Subbarow, 1925. The colorimetric determination of phosphorus. J. Biol. Chem., 66: 375-400. http://www.jbc.org/cgi/content/citation/66/2/375
27. Hsu, S.M., L. Raine and H. Fanger, 1981. Use of Avidin-Biotin Peroxidase Complex (ABC) in immunoperoxidase techniques: A comparison between ABC and unlabeled antibody (PAP) procedures. J. Histochem. Cytochem., 29: 577-580. http://www.ncbi.nlm.nih.gov/pubmed/6166661

28. Goldner, M. and G. Gomori, 1943. Alloxan induced diabetes. J. Endocrinol., 33: 297-299.

29. Doda, R.F., 1996. Diabetes Mellitus. In: Clinical Chemistry, Kaplan, L.A. and J.P. Amadeo (Eds.). Mosby Year Book, St Louis, pp: 613-641.

30. Prince, P.S.M., V.P. Menon and L. Pari, 1997. Effect of Syzigium cumini extracts on hepatic hexokinase and glucose 6-phosphatase in experimental diabetes. Phytother. Res., 11: 529-531. http://cat.inist.fr/?aModele $=$ afficheN\&cpsidt $=2858$ 882

31. Arora, E., S. Shenoy and J.S. Sandhu, 2009. Effects of resistance training on metabolic profi le of adults with type 2 diabetes. Indian J. Med. Res., 129: 515-519. PMID: 19675378

32. Mayes, W.M., 1983. Regulation of Carbohydrates and Lipid Metabolism. In: Harper's Review of Biochemistry, Martine, J.R., V. Rodwell and W. Lange (Eds.), 19th Edn., Medical Publication, pp: 248-264.

33. Tuvemo, T., U. Ewald, M. Kobboh and L.A. Proos, 1997. Serum magnesium and protein concentrations during the first five years of independent diabetes in children. Acta Paediatr. Suppl., 418: 7-10. http://cat.inist.fr/?aModele $=$ afficheN\&cpsidt $=2600$ 784

34. Mauer, S.M., M.W. Steffes and D.M. Brown, 1981. The kidney in diabetes. Am. J. Med., 70: 63-66. http://www.ncbi.nlm.nih.gov/pubmed/7011015

35. Almdal, J.P. and H. Vilstrup, 1988. Strict insulin therapy normalizes organ nitrogen contents and the capacity of urea nitrogen synthesis in experimental diabetes in rats. Diabetologia, 31: 114-118.

36. Mansour, H.A. and A.A. Newairy, 2000. Amelioration of impaired renal function associated with diabetes by Balanites aegyptiaca fruits in streptozotocin-induced diabetic rats. J. Med. Res. Inst., 21: 115-125.

37. Aurell, M. and S. Bjorck, 1992. Determination of progressive renal disease in diabetes mellitus. Kidney Int., 41: 38-42. http://www.ncbi.nlm.nih.gov/pubmed/1614066 
38. Saeed, A., N. Ibrahim, S. Bashandy and S. El-Gengaihi, 1995. Saponin of balanites aegyptiaca del fruits and biological evaluation. Bull. Facility Pharm., 33: 105-109.

http://www.accessmylibrary.com/coms2/summary_ 0286-32584756_ITM

39. Ganong, W.F., 2001. Endocrine Metabolism and Reproductive Function. In: Review of Medical Physiology, Ganong, W.F. (Ed.), 20th Edn., McGraw, pp: 271-306.
40. Begum, N. and K.R. Shanmugasundaram, 1978. Transaminases in experimental diabetes. Arogya J. Health Sci., 4: 116-22.

41. Kumar, P. and M. Clark, 2005. Liver, Biliary Tract and Pancreatic Disease. In: Clinical Medicine, Kumar, P. and M. Clark (Eds.), 6th Edn., Elsevier, pp: 347-417. 